\title{
Juvenile idiopathic arthritis treated with biological therapies
}

\author{
Maria Luisa Velloso Feijoo ${ }^{*}$, Rosalia Martinez Perez, Julia Uceda Montañes, Jose Luis Marenco de la Fuente \\ From 7th European Workshop on Immune-Mediated Inflammatory Diseases \\ Noordwijk aan Zee, the Netherlands. 28-30 November 2012
}

\section{Background}

Biological therapies have dramatically changed the prognosis for children with juvenile idiopathic arthritis (JIA). There are doubts about the possibility of discontinuing treatment once remission is achieved. We focus in this question in our series.

\section{Objective}

To assess the efficacy and safety of these drugs in our series of patients with JIA.

\section{Materials and methods}

We identified 9 children with JIA treated with biologic therapies, and we made a description of our experience.

\section{Results}

The mean age was $14.55 \pm 5.85$, with a female predominance (66.7\%). At diagnosis, mean age was $4.94 \pm 2.9$, and at the beginning of biological treatment of $8.77 \pm 2.63$. The median time from diagnosis to initiation of biological therapy was $3.94 \pm 2.83$ years. The disease characteristics are detailed in the table.

All the children had previously received DMARDs (66.6\% methotrexate (MTX) and 33.3\% MTX and sulfasalazine). Eight of the 9 patients (88.9\%) were taking corticosteroids at baseline. Eight received etanercept (ETN) and one Adalimumab (ADA), with good outcomes in all the patients unless 1 that had to switch from ETN to ADA due to inefficacy, and improved after the change. The steroids were suspended in $75 \%$ of children (6). Differences between mean values of CRP, ESR, and platelets from baseline to actual moment were statistically significant.

The median biologic time is 4 (1.11) years.

Actually all the children are in remission, two of them (patients 1 and 4) without biological treatment or classic DMARDs (since 5 and 2 years respectively).

None of the children have had significant adverse effects nor required hospitalization from the beginning of therapy.

Table 1

\begin{tabular}{|c|c|c|c|c|c|c|c|}
\hline Patient & Sex & Age & Type & RF & ANA & Uveitis & Swollen joints \\
\hline 1 & Female & 10 & Systemic & Negative & Positive & No & Knee \\
\hline 2 & Female & 13 & Polyarticular & Negative & Negative & No & Knee and wrists \\
\hline 3 & Male & 10 & Systemic & Positive & Positive & No & Knee and wrists \\
\hline 4 & Female & 10 & Polyarticular & Negative & Negative & No & Temporomandibular and wrists \\
\hline 5 & Female & 11 & Polyarticular & Negative & Negative & No & Wrists and metatarsophalangea \\
\hline 6 & Male & 7 & Oligoarticular & Negative & Negative & No & Ankles \\
\hline 7 & Male & 7 & Oligoarticular & Negative & Negative & No & Knees \\
\hline 8 & Female & 5 & Oligoarticular & Negative & Positive & Yes & Knees \\
\hline 9 & Female & 6 & Oligoarticular & Negative & Negative & No & Ankles \\
\hline
\end{tabular}

Rheumatology Unit, Valme University Hospital, Seville, Spain

(c) 2012 Velloso Feijoo et al; licensee BioMed Central Ltd. This is an Open Access article distributed under the terms of the Creative 


\section{Discussion}

ETN has proved its efficacy in JIA (regardless of the type of onset), as it has been reported in multiple efficacy and safety studies, including long term studies of up to eight years of continuous therapy.

We present our experience in children treated with up to 11 years, with good outcomes in terms of efficacy and safety in all the patients, and also 2 patients still in remission after 2 and 5 years without treatment.

Published: 28 November 2012

\section{References}

1. Giannini $E H$, et al: Long-term safety and effectiveness of etanercept in children with juvenile idiopathic selected categories of arthritis. Arthritis Rheum 2009, 60(9):2794-2804.

2. Pratsidou-Gertsi P, Trachana M, Pardalos G, Kanakoudi-Tsakalidou F: A follow-up study of juvenile idiopathic arthritis Patients with etanercept discontinued due to Who disease remission. Clin Exp Rheumatol 2010, 28(6):919-22, Epub 2011 Jan 4.

doi:10.1186/1479-5876-10-S3-P46

Cite this article as: Velloso Feijoo et al:: Juvenile idiopathic arthritis treated with biological therapies. Journal of Translational Medicine 2012 10(Suppl 3):P46.

Submit your next manuscript to BioMed Central and take full advantage of:

- Convenient online submission

- Thorough peer review

- No space constraints or color figure charges

- Immediate publication on acceptance

- Inclusion in PubMed, CAS, Scopus and Google Scholar

- Research which is freely available for redistribution

Submit your manuscript at www.biomedcentral.com/submit 